\title{
LEADERSHIP DEVELOPMENTS IN SLOVENIAN COMPANIES
}

Andrej Kohont, Assistant Professor, Ph.D.,

University of Ljubljana, Faculty of Social Sciences, Kardeljeva pl. 5, 1000 Ljubljana, Slovenia, andrej.kohont@fdv.uni-lj.si, ++386-1-5805-236.

\begin{abstract}
In this paper we study the relationship between the company and the leaders. We are interested what is characteristic of leadership in the best Slovenian companies. We used standardised employee questionnaire and data gathered in the Golden thread project. We observe the situation in these companies in the period between 2007 and 2014 to find out if there are any significant changes in leadership developments. Special attention in leadership observation is devoted to 1 . The fundamental relationship between the company and the leaders, 2. The role and quality of leaders work, 3. Organizational culture, climate and relationships, 4. Entrepreneurship and innovation, 5 . The quality of the working environment, 6 . The personal growth and development and 7. Emotional commitment. The analysis represents an insight into current leadership situation and shows that the recent developments were heavily marked by the economic crisis, especially in 2009.
\end{abstract}

Key words: leadership, best Slovenian employers, Golden thread

\section{Introduction}

In this paper we study the relationship between the company and the leaders. We are interested what is characteristic of leadership in the best Slovenian companies. We observe the situation in these companies in the period between 2007 and 2014 to find out if there are any significant changes in leadership, due to the contextual factors outside the company (the economic crisis from 2009 onwards).

We use the data from the Golden Thread project, which is implemented yearly in the best Slovene companies from the year 2007 on. The paper is based on the responses of 8415 leaders from 613 companies in the period studied. Data are gathered through standardised employee questionnaire. From 2007 to 2011 the questionnaire was divided into next six areas: 1. the fundamental relationship between the company and the employees, 2 . the role and quality of work of the individual, 3 . organizational culture, climate and relationships, 4. entrepreneurship and innovation, 5. the quality of the working environment and 6. personal growth and development. In 2012 emotional commitment was added to the previous six areas. In all seven areas the 5point scale is used, where 1 means that the statement is absolutely not true and 5 that the statement is absolutely true. The Golden Thread project results in the selection and the promotion of »best employers of the year « (national competition) as well as the dissemination of the list of top 10 employers and their good HRM practices. The detailed and systematic monitoring of HRM practices developed into an innovative platform that sped up not only the exchange of best HRM practices, but also research, stimulating a range of subnetworks and new services(Bučar et al., 2010).

\section{On leadership}

According to Bryman (2011) leadership can be understood as a process which comprises essential social interactions between the leader and the guided employees. We understand it as a process in which the leader, based on his competency, guide the employees to the agreed goals. Hogg (2005 in Bryman, 2011) placed a broad assertion that leadership is a process of relations and relationships in which some people 
(leaders) influence others and inoculate them with certain values, behaviours, and goals.

There is no common definition of leadership yet. A great deal of scholarship over the past 30 years has been devoted to the analysis and comparison of different leadership styles. Much of this work has dealt with transactional, transformational, and charismatic leadership (Bass, 1985; Avolio and Bass, 1988; Conger and Kanungo, 1987), whereas more recent work is beginning to address styles and approaches such as authentic (Avolio and Gardner, 2005), servant (de Waal et al., 2014; Ago, 2009), and responsible leadership and the need for 'distributed leadership' and empowered co-workers and associates (Waldman and Galvin, 2008). These efforts have provided a better understanding of how the influence of leadership styles is reflected in individual, team, and group performance outcomes (Carter and Greer, 2013).

Pettigrew (1990) considers that there is a lack of emphasis on the interaction between leadership and competitiveness. Leadership effectiveness, depends upon: (a) the extent to which people follow and give legitimacy (this can be termed internal validation), and (b) the extent to which the unit or organization succeeds and survives (this may be termed external validation). There must also be a time dimension to the judgements; this may be short, medium or long term. This further implies that the judgement of the effectiveness of leadership may fluctuate (Weick, 1995).

Important path in leadership literature is focused on the key competences of leaders, such as: adaptive capacity; an ability to engage others in shared meanings, voice, and integrity (Storey, 2011). In his recent description of what he believes are the central hallmarks of leadership Bennis's (2009) enumerates: the ability to find meaning in negative situations, a compelling voice, integrity and adaptive capacity. However, some have argued that beneath the variety there are a number of more or less commonly agreed core capabilities as having and displaying vision, strategic sense, an ability to communicate that vision and strategy, and an ability to inspire and motivate (Council for Excellence in Management \& Leadership, 2001).

Findings from a three-year research project by Tamkin and colleagues from the Work Foundation (Tamkin et al., 2010), suggests that 'outstanding leadership' is a subtle process. It is, they conclude, more effective when it is people oriented, in the sense of being able to elicit commitment from people, than when based on cruder forms of target setting and measurement. Current work on behavioural requirements and capabilities is very varied but it can be organized into three main categories - or what might be termed meta-capabilities. These are: big-picture sense making, the ability to deliver change and interorganizational representation (Storey, 2011).

Important characteristic of leadership work is about the management of change. The main challenges when it comes to making changes is mainly connected with how to find the new and better ways to motivate employees through rewards and recognition, to satisfy their expectations and needs, how to win them and to persuade them to be totally committed to change. Leaders have to rationalize the vision, inspire, and communicate. It is vital they develop a common culture which is based on people recognition, their empowerment, participation, creativity and innovation. Leaders are catalysts of employee engagement -the cognitive, emotional, and behavioural energy an employee directs toward positive 
organizational outcomes (Shuck et al. 2014). Engaged employees are more likely to be productive, they remain with their current employer and interact positively with customers (Schaufelli, 2012; Saks, 2006).

Researchers and practitioners have devoted limited attention to the impact of different sources of leadership support on follower outcomes. Supportive leader behaviours help to reduce stress and result in subordinate reports of greater satisfaction with their leader and their job (Basford et al., 2012). Supportive leadership may even have a positive impact on follower performance, perhaps in part because it may increase followers' motivation to do extra work for their leader. Studies examining perceived supervisor support find it to be negatively associated with turnover, intention to quit, and burnout (Basford et al., 2012). Reductions in staff turnover because of supportive supervisors can benefit organizations by retaining valuable employee knowledge, reducing hiring costs, and minimizing unnecessary training expenses.

From a strategic management perspective, the need for leadership is currently often addressed in terms of the 'reputational capital' that a celebrated leader can bring to an organization. This is a very interesting and revealing concept because it highlights the importance of stakeholder perception. By extension, 'leadership', under certain cultural and economic conditions, becomes a vital intangible asset to an organization. It becomes virtually a component of the brand and is potentially just as valuable (Storey, 2015).

\section{Leadership in the best Slovenian companies}

As we pointed out at the beginning the data are based on the Golden thread project for the period from 2007 to 2014.85 to 100 Slovenian companies annually participated within this project. Among them are 17 companies that participate in the selection in all the years, remaining composition of the sample varies by year, but the size structure (small, large and medium-sized companies) is relatively comparable which allows the comparison of data over the years.

In 2014,83 companieswith 764 leaders participated in the project. Their structure is mostly covered with small $(51.8 \%)$ and medium-sized companies (33.7\%) and with a smaller proportion of large companies $(14.5 \%)$, thus the size structure of companies is close to the actual structure of the Slovenian economy. In the sample dominate services $(56.3 \%)$, production (21.2\%), ICT and R\&D (22.6\%) and trade $(12.5 \%)$ companies. Created added value per employee was $€ 62,680$, which is almost half higher than the Slovenian average from that period and indicates that participating companies are economically successful. $62.8 \%$ of the involved companies in 2014 believes that they are market leaders, and $29.5 \%$ of them are market challengers. They are oriented to foreign markets, with $25.1 \%$ of the revenue generated from sales in foreign markets. They are operating on average at 11 markets and $49.1 \%$ of their revenue is generated in the EU markets and the markets of former Yugoslavia (15.1\%) (Makovec and Brenčič Raskovic, 2014).

Let's look at the characteristics of these companies from the perspective of leaders. Tables from 1 to 7 list the average values of estimates made by leaders in the seven areas of the Golden Thread project, using the 5 point scale. 
(JPMNT) Journal of Process Management - New Technologies, International

Vol. 4, No.2, 2016.

Table 1: Relationship between the company and the leader

\begin{tabular}{|l|l|l|l|l|l|l|l|l|}
\hline COMPANY-LEADER RELATIONSHIP & 2007 & 2008 & 2009 & 2010 & 2011 & 2012 & 2013 & 2014 \\
\hline I understand what is expected of me at work. & 4,46 & 4,49 & 4,53 & 4,53 & 4,53 & 4,50 & 4,54 & 4,57 \\
\hline I have proper means to reach the desired goals. & 3,86 & 3,96 & 3,98 & 4,02 & 4,05 & 4,09 & 4,06 & 4,19 \\
\hline $\begin{array}{l}\text { My contribution to the success of the company is } \\
\text { properly rewarded. }\end{array}$ & 3,26 & 3.48 & 3,44 & 3,59 & 3,62 & 3,64 & 3,68 & 3,80 \\
\hline $\begin{array}{l}\text { I feel safe in this company. } \\
\text { Work in a company gives me more than just a }\end{array}$ & 3,93 & 4,04 & 4,01 & 4,03 & 4,08 & 4,11 & 4,02 & 4,18 \\
\hline \begin{tabular}{l} 
financial reward. \\
\hline
\end{tabular} & 4,02 & 3,93 & 4,03 & 4,06 & 4,12 & 4,13 & 4,19 \\
\hline
\end{tabular}

The relationship between the company and the leaders is improving from 2007 onwards, as the perceived average values of most variables grow. Differences between the values between the years are statistically significant $(\mathrm{p} \leq 0,05)$. There are only some variables in which we observe a decline in 2009: "My Contribution to the success of the company is rewarded properly.", "I feel safe in this company." and "Work in a company gives me more than just a financial reward."

Table 2: Quality of leaders`work

\begin{tabular}{|l|c|c|c|c|c|c|c|c|}
\hline QUALITY OF LEADERS WORK & 2007 & 2008 & 2009 & 2010 & 2011 & 2012 & 2013 & 2014 \\
\hline At work I use only some of my abilities at work. & 3,23 & 3,09 & 3,06 & 2,94 & 2,99 & 2,93 & 2,93 & 2,85 \\
\hline Tasks that are entrusted to me are over demanding. & 1,54 & 1,48 & 1,54 & 1,49 & 1,54 & 1,56 & 1,58 & 1,58 \\
\hline $\begin{array}{l}\text { I realize the impact of my work on my colleagues } \\
\text { work. }\end{array}$ & 4,44 & 4,45 & 4,53 & 4,47 & 4,47 & 4,50 & 4,62 & 4,57 \\
\hline $\begin{array}{l}\text { In the last month I received a praise for a good } \\
\text { work form my superior. }\end{array}$ & 3,02 & 3,27 & 3,10 & 3,38 & 3,29 & 3,49 & 3,45 & 3,60 \\
\hline $\begin{array}{l}\text { For my supervisors or employees I am not just a } \\
\text { number. }\end{array}$ & 3,81 & 3,92 & 3,83 & 3,99 & 3,99 & 4,01 & 4,05 & 4,13 \\
\hline $\begin{array}{l}\text { At work there is a very little unnecessarily wasted } \\
\text { time, energy or money. }\end{array}$ & 3,13 & 3,28 & 3,27 & 3,37 & 3,36 & 3,42 & 3,43 & 3,56 \\
\hline I enjoy working in this company. & 3,83 & 4,00 & 3,97 & 4,00 & 4,08 & 4,09 & 4,13 & 4,15 \\
\hline My work gives me a feeling of success. & 3,87 & 4,01 & 3,97 & 4,06 & 4,09 & 4,10 & 4,14 & 4,14 \\
\hline
\end{tabular}

Also in the field Quality of leaders'work increase in the average values of observed statements from the questionnaire is evident. Decline is traced in next statements for 2009: "In the last month I received a praise for a good work form my superior.", "For my supervisors or employees I am not just a number." "I enjoy working in this company.", and "My work gives me a feeling of success." There is also a lesser decline in 2010 in statements: "I realize the impact of my 
work on my colleagues` work." and "At work there is a very little unnecessarily wasted time, energy or money."

Table 3: Organizational culture, climate and relationships

\begin{tabular}{|l|l|l|l|l|l|l|l|l|}
\hline $\begin{array}{l}\text { ORGANISATIONAL CULTURE, CLIMATE } \\
\text { AND RELATIONSHIPS }\end{array}$ & 2007 & 2008 & 2009 & 2010 & 2011 & 2012 & 2013 & 2014 \\
\hline I am proud that I am a member of this company. & 4,22 & 4,34 & 4,27 & 4,33 & 4,41 & 4,39 & 4,42 & 4,49 \\
\hline Management sets good examples of proper work. & 3,39 & 3,60 & 3,49 & 3,65 & 3,71 & 3,75 & 3,74 & 3,86 \\
\hline $\begin{array}{l}\text { Management communicate openly with } \\
\text { employees. }\end{array}$ & 3,30 & 3,49 & 3,40 & 3,59 & 3,62 & 3,71 & 3,69 & 3,83 \\
\hline $\begin{array}{l}\text { I am happy for my coworkers' success. } \\
\text { Management communicates respectfully with } \\
\text { employees. }\end{array}$ & 3,54 & 3,74 & 3,68 & 3,80 & 3,89 & 3,87 & 3,91 & 4,00 \\
\hline $\begin{array}{l}\text { Work in the company is based on collegial } \\
\text { relations. }\end{array}$ & 3,77 & 3,94 & 3,90 & 3,92 & 3,94 & 3,99 & 4,08 & 4,12 \\
\hline $\begin{array}{l}\text { The company promotes the right people. } \\
\text { The company's understands my private life and } \\
\text { needs. }\end{array}$ & 3,51 & 3,73 & 3,63 & 3,76 & 3,83 & 3,84 & 3,90 & 3,95 \\
\hline
\end{tabular}

In the field of culture, climate and relationships we can also talk about growth and development of the culture, which supportsleadership. The largest deviation from the development of this "leaders supporting culture" is observed in the year 2009 , when the average values fall downin 6 out of 8 monitored dimensions. Differences between the years are statistically significant.

Table 4: Entrepreneurship and innovation

\begin{tabular}{|l|c|c|c|c|c|c|c|c|}
\hline ENTREPRENEURSHIP AND INNOVATION & 2007 & 2008 & 2009 & 2010 & 2011 & 2012 & 2013 & 2014 \\
\hline I plan my work independently. & 3,70 & 3,86 & 3,77 & 3,92 & 3,90 & 3,92 & 4,02 & 4,00 \\
\hline $\begin{array}{l}\text { I independently choose the ways and means to } \\
\text { achieve business goals. }\end{array}$ & 3,66 & 3,79 & 3,70 & 3,82 & 3,79 & 3,79 & 3,97 & 3,95 \\
\hline $\begin{array}{l}\text { I contribute to the improvements and new } \\
\text { approaches at work. }\end{array}$ & 4,11 & 4,24 & 4,12 & 4,24 & 4,22 & 4,28 & 4,31 & 4,36 \\
\hline $\begin{array}{l}\text { In the company count suggestions, ideas and } \\
\text { proposals. }\end{array}$ & 3,71 & 3,89 & 3,78 & 3,92 & 3,94 & 4,04 & 4,02 & 4,16 \\
\hline The company is learning from mistakes. & 3,28 & 3,54 & 3,41 & 3,58 & 3,58 & 3,73 & 3,84 & 3,86 \\
\hline Learning is a value of our company. & 3,96 & 4,11 & 3,97 & 4,09 & 4,09 & 4,10 & 4,13 & 4,26 \\
\hline
\end{tabular}


Also in the field of Entrepreneurship and Innovation applies that over the period of study,average values of individual dimensions grow. Here stand out statements: "Learning is a value of our company.", "I contribute to the improvements and new approaches at work.", and "In the company count suggestions, ideas and proposals." Also in this area the largest decline is evident in 2009 , as the reflection of the economic crisis.

Table 5: The quality of the working environment

\begin{tabular}{|l|l|l|l|l|l|l|l|l|}
\hline $\begin{array}{l}\text { THE QUALITY OF THE WORKING } \\
\text { ENVIRONMENT }\end{array}$ & 2007 & 2008 & 2009 & 2010 & 2011 & 2012 & 2013 & 2014 \\
\hline Working time arrangements suit me. & 4,04 & 4,20 & 4,13 & 4,23 & 4,30 & 4,27 & 4,30 & 4,35 \\
\hline I also work outside my working hours. & 3,77 & 3,81 & 3,78 & 3,78 & 3,81 & 3,72 & 3,74 & 3,58 \\
\hline My working time is too long. & 2,57 & 2,56 & 2,46 & 2,44 & 2,43 & 2,41 & 2,39 & 2,32 \\
\hline $\begin{array}{l}\text { The company sets too short deadlines for reaching } \\
\text { the goals. }\end{array}$ & 2,68 & 2,63 & 2,58 & 2,56 & 2,56 & 2,48 & 2,50 & 2,42 \\
\hline $\begin{array}{l}\text { The work intensity is too high. } \\
\text { I have personal experience with discrimination at } \\
\text { work in this company. }\end{array}$ & 1,94 & 1,83 & 1,87 & 1,70 & 1,74 & 1,76 & 1,65 & 1,60 \\
\hline
\end{tabular}

Most of the leaders are satisfied with their working arrangements. Since 2007 the average values concerning the length of working time, the deadlines for achieving the objectives and the intensity of work is declining. Nevertheless, there are still many leaders who work for a company outside their working time (average value $3.58)$.

Table 6: Personal growth and development

\begin{tabular}{|l|c|c|c|c|c|c|c|c|}
\hline $\begin{array}{l}\text { PERSONAL GROWTH AND } \\
\text { DEVELOPMENT }\end{array}$ & 2007 & 2008 & 2009 & 2010 & 2011 & 2012 & 2013 & 2014 \\
\hline $\begin{array}{l}\text { In the last year I had a talk about my progress } \\
\text { at work. }\end{array}$ & 3,37 & 3,51 & 3,26 & 3,65 & 3,46 & 3,52 & 3,35 & 3,57 \\
\hline $\begin{array}{l}\text { In the last year I had the opportunity to learn a } \\
\text { lot at work. }\end{array}$ & 3,82 & 4,01 & 3,86 & 4,03 & 4,01 & 4,07 & 4,11 & 4,09 \\
\hline $\begin{array}{l}\text { Employment in this company increases my } \\
\text { employment possibilities elsewhere. }\end{array}$ & 3,69 & 3,97 & 3,75 & 3,93 & 3,89 & 3,96 & 3,98 & 4,06 \\
\hline $\begin{array}{l}\text { There is a person at work who encourages my } \\
\text { development. }\end{array}$ & 3,32 & 3,56 & 3,42 & 3,62 & 3,64 & 3,70 & 3,73 & 3,78 \\
\hline
\end{tabular}


The leaders mainly report that companies provide them the opportunities for their personal growth and development. The exception is again shown in 2009, when the average values for all analyzed dimensions decreased. The challenge in this area remains annual interview about progress in the workplace.In this dimension we can observe growth followed by drop indicating an unstable application of progress interviews in the observed companies.

\section{Table 7: Emotional commitment}

\begin{tabular}{|l|l|l|l|}
\hline EMOTIONAL COMMITMENT & 2012 & 2013 & 2014 \\
\hline I would love to spend the rest of my career in this company. & 4,10 & 4,11 & 4,13 \\
\hline $\begin{array}{l}\text { I like to discuss about my company with people outside the } \\
\text { company. }\end{array}$ & 3,82 & 3,79 & 3,81 \\
\hline I feel companies problems are also my problems. & 3,93 & 4,03 & 3,99 \\
\hline I would be easily attached to another company. & 2,75 & 2,69 & 2,66 \\
\hline I do not feel like a family member in this company. & 2,20 & 2,06 & 2,00 \\
\hline I do not feel emotionally attached to this company. & 2,05 & 1,96 & 2,03 \\
\hline Company means a lot to me personally. & 4,15 & 4,28 & 4,20 \\
\hline I do not have a strong sense of belonging to the company. & 1,67 & 1,69 & 1,65 \\
\hline
\end{tabular}

Emotional Commitment is monitored since 2012, so it is difficult to evaluate the trends in this area. Individual average estimates suggest that leaders are emotionally committed, as they evaluate next statementshigh:"Company means a lot to me personally.","I would love to spend the rest of my career in this company." and very lowstatements: "I do not have a strong sense of belonging to the company.", I do not feel like a family member in this company.", and "I do not feel emotionally attached to this company."

\section{Conclusions}

To creatively lead the workflow, achieve goals, contribute to the results of their coworkers and followers, and strengthen the inclusive relations, leaders must have opportunities to create an appropriate work environment that supports creativity. The cornerstone of this is to build trust and create a corporate culture that allows individuals and teams to develop new ideas and to give free rein to expression.

The situation in Slovenian companies in the analyzed period reflects positive developments inthe enhancement ofleadership role and in inclusive leadership. Based on the highest estimated average values of the statements in the questionnaire,leaders are most satisfied with the following aspects of the support provided to them by the company and its management: 


\section{COMPANY-LEADER RELATIONSHIP}

1. I understand what is expected of me at work.

2. Work in a company gives me more than just a financial reward.

3. I have proper means to reach the desired goals.

QUALITY OF LEADERS`WORK

1. I realize the impact of my work on colleagues`work.

2. I enjoy working in this company.

3. My work gives me a feeling of success. ORGANISATIONAL CULTURE, CLIMATE AND RELATIONSHIPS

1. I am happy for my coworkers' success.

2. I am proud that I am a member of this company.

3. Work in the company is based on collegial relations.

\section{ENTREPRENEURSHIP AND INNOVATION}

1. I contribute to the improvements and new approaches at work.

2. Learning is a value of our company.

3. In the company count suggestions, ideas and proposals.

THE QUALITY OF THE WORKING

ENVIRONMENT

1. Working time arrangements suit me.

2. The work intensity is too high.

3. My working time is too long.

PERSONAL GROWTH AND DEVELOPMENT

1. In the last year I had the opportunity to learn a lot at work.

2. Employment in this company increases my employment possibilities elsewhere.

3. There is a person at work who encourages my development.

EMOTIONAL COMMITMENT

1. Company means a lot to me personally.

2. I would love to spend the rest of my career in this company.

3. I feel companies` problems are also my problems.

In the relationship between the leaders and the company it can be observed, that leadersincreasingly clearly understand what is expected of them at work. They perceive their work as content full, which also contributes to the understanding of their work impacts on the work of their co- workers and followers, to their joy at work and to their feelings of success for the achievements. At the same time leaders'work in the best Slovenian companies is based of collegial relationships and looking forward to the success of their co-workers.

The results also show that leaders have adequate resources to achieve the expected goals. In terms of innovation and creativity and achievement of objectives, the observation of leaders concerning learning as a high company value, is very important. Furthermore, the proposals and ideas of leaders and their contribution to the improvement and introduction of new approaches is appreciated in the companies. An important component of creative work is also time for the maturation of ideas. From this perspective, leaders ' perceptions about the allocation of work, work intensity and length of working time can be very positively evaluated. Thissignificantly deviates from the Slovenian average, characterized by high intensity and scope of work (KanjuoMrčela and Ignjatović, 2012). Field of leaders`personal growth and development, reflects the characteristics of a learning culture in the studied companies. Leaders have many opportunities for learning at work, and co-workers who promote their development, which at the same time strengthen their own employment opportunities. Their commitmentis confirmed in the questionnaire statements: they are proud members of the company, the company personally means a lot to them and they want to build their career in it.

The challenge for the future, based on the lowest average value of the statements, is the rewardingof leaders for their contributions, since they estimate that the rewards are too low. They also reported that they are rarely praised by their 
superior, and they do not talk enough about their progress at work. Some room for improvements is also within the use of leaders`capabilities at work and within a more efficient use of time, energy and money. Management by good examples, openness in communication with management, and emphasis on the promotion of competent individuals could be further strengthen. The leaders also warn that organizations learn too little from their own mistakes. From the perspective of their independence at work, leaders estimate they could morelargely self-select the ways and means to achieve the planed objectives and work. Despite the aforementioned relatively good consistency of working time, statement that leaders work outside working hourscomes to the fore.

\section{COMPANY-LEADER RELATIONSHI}

My contribution to the success of the company is properly rewarded.

\section{QUALITY OF LEADERS`WORK}

At work I use only some of my abilities at work.

At work there is a very little unnecessarily wasted time, energy or money.

In the last month I received a praise for a good work form my superior.

ORGANISATIONAL CULTURE, CLIMATE AND RELATIONSHIPS

Management sets good examples of proper work.

Management communicate openly with employees.

The company promotes the right people.

\section{ENTREPRENEURSHIP AND INNOVATION}

The company is learning from mistakes.

I independently choose the ways and means to achieve business goals.

I plan my work independently.

\section{THE QUALITY OF THE WORKING ENVIRONMENT}

I also work outside my working hours.

\section{PERSONAL GROWTH AND DEVELOPMENT}

In the last year I had a talk about my progress at work.

\section{EMOTIONAL COMMITMENT}

I would be easily attached to another company.

I do not feel emotionally attached to this company.

What is thus the message of the project, who puts in front the relationship between the company and the employees (leaders)? The differences in estimates are small, but bear a few important messages. Relations between companies and leaders in the studied companies are stable. The participating companies, despite external influences, understand that the key to success is a long-term orientation with a human face. The Gold thread indicates that the good relationship between the companies and individuals is appreciated. It contributes to the success and offers support even in uncertain times. The activities carried out by companies in the areas of leadership, quality of work and the working environment, culture, climate, personal growth and development thus leave their mark and contribute to finding solutions. Also, due to the difficult market conditions and still present climate of crisis, it is essential to maintain and strengthen them. The key remains in leadership. Leaders are agents of change who inspire co-workers and provide an environment for their implementation. Therefore it is vital that they are effective, focused onthe knowledge development, with an ear for co-workers, and at the same time exemplary, since only then they will lead to the agreed objectives. 


\section{Research limitations}

Approach based on the Golden Thread has also some limitations worth noticing and taken into consideration for further research. The analysis includes only leaders. For further exploration it would be reasonable to include also the views of their co-workers and managers.

The analysis is based on average values in the observed areas, which are differentiated by years of data coverage. It further research it would be possible to focus on the differences in the size of companies or in sectors, which were mentioned in the description of the participating companies of 2014, but not described in detail for other years of project conduction. Authors have pointed up the importance of industry sector as a factor influencing receptivity to different types of leadership. For example, the leading analysts of transformational and charismatic leadership (Bass 1985; Avolio and Gardner, 2005) have noted how sector plays a part in the way these roles are performed, how effective they are and how they are perceived (Storey, 2011).

As our contribution is based on the analysis of secondary data, the structure and content of the questionnaire represents a restriction in the depth of debate itself, and determines the scope of analysis. Consequently, we did not start from a prestructured theoretical concept or from a particular model of leadership, but we used the data to primarily investigate the situation and determine the characteristics of leadership in the best Slovenian employers. Thus, we got avaluable insights into the situation, which might be helpfulfor further research on one side, and on the other side presents an image of Slovenian leadership to business practitioners, that can be the starting point for futureimprovements in their companies.

\section{References}

- Ago, A. (2009):Perspectives of senior level executives on leadership and followership, Journal of Leadership \& Organizational Studies, 16 (2): 159-66.

- Avolio, B. and Bass, B. (1988): Transformational leadership, charisma and beyond, in J. Hunt, H. Baliga and C. Dachler (eds), Emerging leadership. Vistas, Lexington, MA: Lexington Books.

- Avolio, B. J. and Gardner, W. L. (2005):Authentic leadership development: getting to the root of positive forms of leadership, The Leadership Quarterly, 16 (3): 315-38.

- Basford, T. E., Offermann, L. R. and Wirtz, P. W. (2012): Considering the Source: The Impact of Leadership Level on Follower Motivation and Intent to Stay. Journal of Leadership \& Organizational Studies, 19(2): 202-214.

- Bass, B. M. 1985.Leadership and performance beyond expectations, Cambridge, MA: Harvard University Press.

- Bennis, W. (2009): On becoming a leader. New York: Basic Books.

- Bryman, Alan. (2011): Leadership and power. In A. Bryman, D. Collinson, K. Grint, B. Jackson and M. Uhl-Bien (eds); The SAGE handbook of leadership. Los Angeles: Sage.

- Bučar, M., Stare, M. and Jaklič, A. (2010): Innovation potential of public and private sectors cooperation in knowledge-intensive services in Slovenia. Naše Gospodarstvo, 56 (5/6): 29-35.

- Carter, S. M. and Greer, C. R. (2013): Strategic leadership: Values, styles, and organizational performance. Journal of Leadership \& Organizational Studies, 20(4): 375-393.

- Council for Excellence in Management and Leadership (2001):Leadership development: Best practice guide for organisations, London: CEML.

- Conger, J. and Kanungo, R. (1987):Towards a behavioural theory of charismatic leadership in organizational settings, Academy of Management Review, 12: 635-47.

- Kanjuo Mrčela, A. and Ignjatović, M. (2012):Psychosocial risks in the workplace in Slovenia. Dublin: European Foundation for the Improvement of Living and Working Conditions.

- MakovecBrenčič, M. and Rašković, M. (2014):Izhod iz krize temelji na zaupanju zaposlenih $\mathrm{v}$ podjetje,Zlata nit. Ljubljana: Dnevnik.

- Northouse, P. G.(2007): Leadership: Theory and practice. Thousand Oaks (CAL): Sage. 
- Pettigrew, A. (1990):Longitudinal field research on change: Theory and practice, Organization Science, 1 (3): 267-92.

- Saks, A. M. (2006): Antecedents and consequences of employee engagement. Journal of Managerial Psychology, 21, 600-619.

- Schaufeli, W. B. (2012): Work engagement: What do we know and where do we go? Romanian Journal of Applied Psychology, 14 (1): 3-10.

- Shuck, B. and Reio, T. G.(2014):Employee engagement and well-Being: A moderation model and implications for Practice. Journal of Leadership \& Organizational Studies, 21(1): 43-58.

- Storey, J. (2011): Leadership in organizations: Current issues and key trends. New York: Routledge.
- Tamkin, P., Pearson, G., Hirsh, W. and Constable, S. (2010):Exceeding expectation: The principles of outstanding leadership, London: The Work Foundation.

- de Waal, A. and Sivro, M. (2014):The relation between servant leadership, organizational performance, and the high-performance organization framework. Journal of Leadership \& Organizational Studies, 19(2): 173-190.

- Waldman, G. A. and Galvin, B. M. (2008):Alternative perspective of responsible leadership. Organizational Dynamics, 37 (4): 327-341.

- Weick, K. W. (1995):Sense making in organizations. Newbury Park, CA: Sage. 